\title{
EXPERIMENTAL SYUDIES OF THE TRANSPLANTAION OF THE MUCOUS MEMBRANE OF THE NOSE IN THE RABBIT
}

\author{
By \\ YuTAKA NOGUTI \\ From the Department of Oto-Rhino-Laryngology, Chiba University, \\ School of medicine (Director: Prof. T. Kitamura)
}

Many cases of metaplasia to stratified squamous epithelium are seen in the atrophic rinitis. The maxillary epithelium also falls in metaplasia after the transplantion to the inferior turbinate by Kubo's maxilloturbinal plasty. We suppose that these changes are caused by many factors but the decrease of the blood supply in the mucosa plays an important role.

A small graft from the septal mucosa of the nose in the rabbit was transplanted to the maxillary sinus. In 4 days the the transplanted graft falls in necrobiosis, but in 14 days regenerates a squamous like epithelium. In 30 days pseudostratified columnar epithelium and a few glands are seen and in 90 days the columnar epithelium matures containining many goblet cells and the glands increase in number.

These regenerative changes co-relate closely with the reconstruction of the vascular network, which was confirmed quantitatively by the photomicrogram of the vascular network of the graft produced by injecting the latex solution from the carotid artery.

The vascular network and the gland in the graft resemble to those in the original maxillary mucosa, and the epithelium becomes that of the nasal membrane.

\section{家鬼鼻粘膜移植の実験的研究}

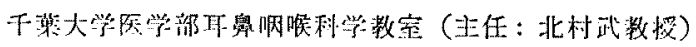

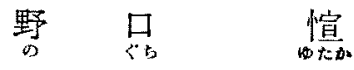

目次

1 藉言

II 実験材料及び笑験方法

1. 实験材料

2. 实融方法

1) 移椎手術

2）組織標本の作䌘及び観察

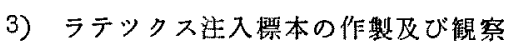

a 旅流液及び灌流装䀧

b 嘫流実験

c 標本作製

d 観察方法

e 小括及び考按

III串鈳 成績

1. 組織媒本
1) 刘 照

2) 移稙粘膜の組織所見

3）涠中澵の粘脱採取部の修得

4) 小括及び考技

2. ラテックス注入標本

1) 対 照

2) 小括及び考按

3）移植片のラテックスによる血管像

4) 小括及び考按

NV 総括及び考按

$V$ 結 諭

\section{I 舶}

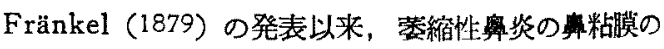
病糸については多くの研究があり，北村によればその主 病变は鼻粘膜の萎縮で，下甲介に著しく，組峨学的变化 
は上皮の扁平化，化生，上皮下組織の線維化，腺の萎 㴼・消失，血管の炎症性変化等である.これらの変化は すぺての症例に必らず見られるというるのではなく，そ の一部を欠くものも多い, 病因についても局所説 (Lautenschläger), 素因説 (Wittmaack, Fleischmann), 内分泌障害説等々の角度から論議が行われているが，そ のいずれをとつても単独で萎縮性鼻炎の原因とは見做し 難く、われわれは 2,3 の原因が重なつて上述の如き变化 を表的す考えるに致つた。

一方移植粘膜及び粘膜欠損部の再生の過程に执いては 一般に上皮の扁平化, 化生の生ずることがよく知られて いる.これらの場合最も強い障害を受ける組織の一つに

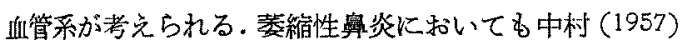
は血管の減少をあげている，著者は家兔を用いて番中隔 粘期を上顎洞へ移植し，移植粘膜及び鼻中㢳粘膜欠損部 の再生過程の組織学的観察を行い，又ラテックス注入標 本により血管の修復過程を観察し，移植粘膜については その数量的観察を行い，組織学的所見との比較を陚又 た.

\section{II 実験材料及び実験方法}

\section{1. 实験材料}

同一条件で飼育した焳の健康成熟白色家東（2.0〜2.5 kg）67羽を使用した。 夫々に次に述べる移植手術を施 行し，表 1 の如く組織標本作製群とラテックス注入䧣本 作製群とに分けた，その他に刘照として各群に3 羽宛無 操作家象による標本を作製した。

\section{表 1}

\begin{tabular}{|c|c|c|c|}
\hline 些龆群 & 術後日数 & 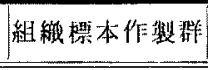 & 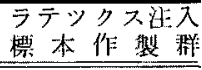 \\
\hline I & 4 & 5 羽 & 3羽 \\
\hline $\mathbb{1}$ & 7 & 4 & 3 \\
\hline$\Pi^{\prime}$ & 10 & 4 & \\
\hline$\llbracket$ & 14 & 6 & 4 \\
\hline $\mathbb{I}^{\prime}$ & 17 & 4 & \\
\hline$N$ & 21 & 6 & 4 \\
\hline$V$ & 30 & 4 & 4 \\
\hline V & 60 & 4 & 5 \\
\hline VII & 90 & 3 & 4 \\
\hline 計 & & 40 & 27 \\
\hline
\end{tabular}

2. 然験方法

1) 移植手術

上記の家雨の背筋内に $25 \%$ ウレタン $7 \mathrm{cc} / \mathrm{kg}$ を注射
し，30〜60 分後に充分麻酔が效いてから家禹を固定し，

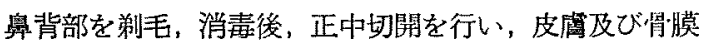
を左右に剩離して畄背部及び上顎洞前壁の骨面を広く露 出し, 先ず右側上腼洞前壁を削開して，上顎菏粘膜を骨 膜下に自然口付近まで可及的完全に剥離除去した。次い で左側血腔前壁の鼻骨及び上顎洞前壁を削開し上顎洞粘 膜及び鼾腔側壁を除き，左側娄中隔粘膜の添ぼ中央部を

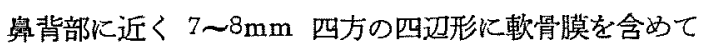
採取し，これを遊離移植粘膜片として，先に粘膜を除去 した在側の上顎洞の内側の骨面上に粘膜片の軟骨面が接 するように置いた。更に，前壁の骨欠損部より洞内への 肉芽組織の侵入に上る移植粘膜片の吸収を防止する目的 で手術用ゴム手袋の小片を隇菌して移植片を覆い更にそ の上に軟くガーゼタンポンを施し固定した，皮膚及び骨 膜の切開創は一次的に縫合して移植手術を終つた，術後 は感染防止のため3日間クロラムフェニコール100 mg の筋注を行つた。. 14 日以上の長期観察群ではゴム片に 上る異物反応防止のため移植粘膜片の着床を待つて 10 日目に鼻背正中部を再切開し，右上㖽洞内のガーゼ及び ゴム片を除去舅背創を縫合した，以上の操作を通して麻 䣲覚醒後家象は元に復し摂食を行い，一部くさめ等を行 うあのもあるが数分後には安静になる.

2) 組織標本の作製及び観察

实験動物の一部は夫々術後所定の日数を絽てから罕気 栓寒により屠殺し，直らに皮處を剝離し，畧根部より切 断, $10 \%$ ホルマリン液で固定しプランク・リチニロの 迅速法で脱灰し，大部分の例は移植粘膜部を通る前額 断，一部は水平断としてバラフイン包埋後，その方向に 6〜8 $\mu$ で薄切し, H・E 染色, マロリ一染色, PAS 染 色，パップの鍍銀染色，ワンギーソン染色を行い検鏡 し, 主として番中隔粘膜（移植片採取部），移植粘膜の 上皮, 粘膜下層, 特に血管の状態を観察した。

3) ラテックス注入標本の作製

前記の粘膜移植手術を行い，所定の日数を経た实験動 物の中から，組織標本を作笠したもの以外の動物を用い た.

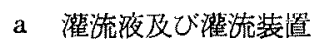

\section{濯 流 液}

i）日本薬局方リンゲル液を使朋し，リンゲル渡 500 $\mathrm{ml}$ に7\%の割にゼラチン，0.5ml のへパリン液， 0.05 \%の割にカフェイン末を扣えた。

ii）相模ゴム工業陎式会社製のラテックス液を俅用 した，同液け安定剤としてアンモニフを加えアルカリ性 
に保当然凝固を防いであり，白色乳濁状で $\mathrm{pH} 10.6$ 〜 10.4, 比粘度 $27 \sim 30$, 比重 $0.97 \sim 0.98$ で熱を加えると $100^{\circ} \mathrm{C}$ で凝固する. 灌流にはこのラテックス液を㩐溜 水で $20 \%$ に稀积し，同腋 $500 \mathrm{ml}$ にホルマリン原液を $16 \mathrm{ml}$ 加え， $\mathrm{pH} 7.27$ ，此粘度 1.5 に調製した。

\section{灌流装置}

2 個の温度 自動調䬣装置付 恒温槽を一定の高さに吊 し，その各々にi）及び ii）の灌流液を入れ，恒温槽よ り点滴静注用ゴム管を接続させ， Y 字型劣゙ラス管によ り合流させ，末端にガラス製動脈力ニユーレを，その回 路中にコツク付点滴装䬸, 水銀マノメーター, 温度計及 びタコ管を取付けた，又整流液流出には2本の静脈カ二 ユーレを使用した。

\section{b 灌流実駼}

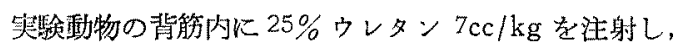
30 分〜60 分待ら麻酔が充分效儿てから仰卧位儿固定し, 頸正中に縦切開を加光, 総頸動脈及び頸静脈を露出し, 右総頸動脈，左右频静脈にカニーレを插入，左総頸動脈 を絬禁し，直らに灌流を開始した，濩流液を入れた恒温 槽は家鬼の坐理的血流状態に可及的に近ずけるため子め $40^{\circ} \mathrm{C}$ に調節しておき，灌流匢が 80 100 $\mathrm{mmHg}$ にな るように色し，灌流液は门最初はのリンゲル液を用い

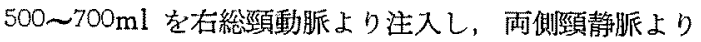
流出せしめ，流出溜か゚殆んど透明となつたとこるで ii) のテックス液を 350〜 500 ml 灌流した．灌流終了时に 生ずることのある全身痤臂を防此すするため，5\%オ一 ロハンソーダ液 $3 \mathrm{ml}$ を灌流完了の直前に注入して死亡 させた. 完了後, 両側の総頸動脈及び頸静脈を結禁し, 5 10 分間とのま青静置し，血管内ララ゙ックスの安定を 待ら断頭した。

\section{c 標本作製}

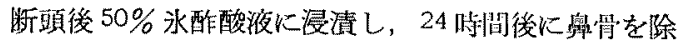
去し，液がよく粘膜に浸漬し得るようにして引続き同液 に2〜3日漫漬し透明棒本を作つた。この閒に骨部は脱

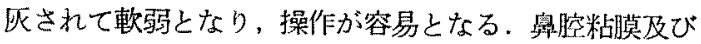
移植秥膜を注意哚く骨より剝離し，日本光学製立体顕微 鏡で血管を観祭し，透過光線で撮影した。

$\mathrm{d}$ 観察方法

刘照とした無操作家束では粘膜を舆中隔前，中，後 部, 僛壁前，中，後部，上顎洞に分け，七の部の任意の

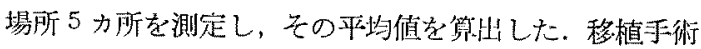

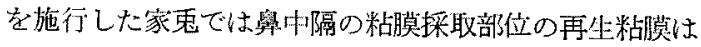
禹背からの㔀離困難なため軟骨をつけたまま観祭した
が，その写真撮影は行わ゙かかた。䕱洞の移植粘膜の 剝離も困難であつたが，これ等は立体澒微鏡下に観察し ながら，銚的あるいは鋭的に㔀離を進め，移植粘膜を可 及的損鹪しないように努力した．移植群の家東でも左側 の褱中隔及び側壁の粘膜には操作が加えていないので刘 照とした家鬼と同様の力法で観察した，写真は全て 35 $\mathrm{mm}$ 版のフイルムを用い，立体顕微鏡の摭大象は 24 倍 として撮影し，印画紙に引伸し筧付けるに当つては，印 画が実物の48倍となるよらに弱伸し倍率を調館した。 網状毛細管の網眼数は印画上で直径 $5 \mathrm{~cm}$ の円内の数で 表わし，䍗物では $0.85 \mathrm{~mm}^{2}$ の円内の数に相当する.

\section{E 小括並びに考接}

鼻粘膜の血管分布に関する報告は Zuckerkand1 (1884) 以来多数の業蹟があり，本邦でも久保，武田，橋本等代 上り詳細に研究されている，碳組血管分布に関しては古 来ベルリンブルー，墨汁等の色素が用いられたが，近年 に至つて合成樹脂，ラテックスを用いて血管系の鋳型を 作製して観察する研究が多い.ラテックスは土居の肝血 管, Trueta 等の腎血管, Marjorie 等の舌血管, Dawes 等により犬，家束等の兽腔血管の矿㐐等に愿々月 いられ，河野もラテックスを用いて正常家鬼及び或験似

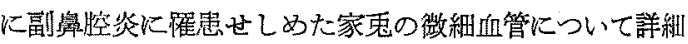
な研究を行つている，河野も述べている如く，ラテック 不は物理化学的性状を血液にほぼ等しくでき，生理的に 無為な水を分散媒とする膠質で血液に最も似て扣り，且 管壁にもよくなしみ，その形態を比較的忠実に示し，強 靱で操作中る損稘が少く，乳濁色のため透過光線での観 察に適し,䣲で軽度に収縮し,アルカリで脚潤して元に厣 るといら性貿のため，著者の武跧には墨汁等の色妻より 優れている事を確認した，家雭の体温その他を予め湘定

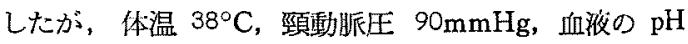
7.3 ，组清の比粘度 1.5 ，血流量 $50 \mathrm{cc} /$ 分とい5河野の湖 定值を再確認し，灌流にはこれ等の值を基準として，可 及的家鬼の生理的状態を保つよらに努めた。麻酔に朋い たウレタンは広く家种知験に朋いられ，白井，山中等は 然麻酔の状態と大差ないとし，河野はやや摭張を示した ようだと述べている，獤細血管の各部位に関する名称は 西丸の分類した如く，小動脈，毛細動眽，分岐毛細管， 網状毛細管，集合毛細管，毛細動脈，小静脈の名称が適 当であるらが，白岩，河野等も指㧩している如く，その 境界を形態力口把えることは難しい。

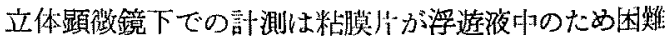
なのですべて写真印画上で行い，骨面よりの血管出入等 
はその観察のみに止め，小動静脈，毛細動静眽は部位に より，㕛写真により不鮮明なのでその計測は行なわなか ot.

\section{III 実験成绕}

\section{1. 組織標本}

1) 対 照

咸中隔の 背側部及びこれに対応する 鼻腔側壁の粘膜 で，肉眼的に暗褐色を呈する部分が嗅部で，唤上皮に覆 われている.上皮細胞恃春の高い多列線毛円柱上皮で， 間化細長い嗅細胞を混ずる、杯細胞はみられない，基底 膜は鍍銀染色，PAS 染色で明瞭に染色される，粘膜固

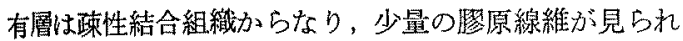
る. 血管は比較的豊富で深層に太いものが多く，静脈の 内腔には多量の血球がある。浅層には多数の喚腺があ り，その多くは漿液腺て唤上皮を鉛直に賈いて開口して いる，鼻中隔軟骨との間には比較的多くの結合織を含む 周が河り軟骨と接している。

鼻底側の乎吸部では上皮は高さのやや低い２列線毛円 柱上皮で，杯細胞を豊富に含む．粘膜固有層は疎灶絬合 織からなり比較的太い、動静脈を有し腺は多数て粘液腺の 占める割合が多い.

本实稌で移植に利用したのは嗅上皮の部及び呼吸部の 一部である。

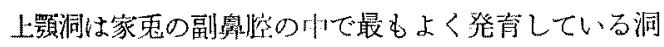
で，前頭洞，蝶形洞，篩骨蜂简の発育は覀い，上顎洞は 上顩骨中にあり，尾側は眼窩に迲し，矢状力向に長く， 自然口は嗅奥甲介つ前部で広く鼻腔に開口寸る，上靧洞 の血管は自然口から洞糊莫に分布するものがその主たる ものであるが，䚘腔側壁，上颚洞前壁の骨を貫いて直接 に分布するものもある．洞粘膜は単層線毛円柱上皮に覆

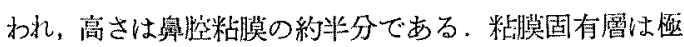
めて䅇な絬合織の基質からなり，少量の粘液腺及び血管 を有する．粘膛固有層をも含めて上颚润粘膜の厚さは爱 空粘膜の約半分である。

2）移植粘膜の組織所見

移植手術施行後予定の日数を絽ずに死亡したものは死 後装化による修飾を考光て除外した，各群の組織所見の 大要は表 2 に示し，各群に特異的な所見を日数別に記述 する.

\section{第!群（術挠 4 日目）}

上皮以 nekrobiotisch で染色性が䍐く，好师球，内 形細胞の強い浸潤及び線維芽緗胞の增尘がある。基底膜 は一部欠除するものもあるが大部分は上く保存されてい
表 2 移植粘膜の組織学的所見

\begin{tabular}{|c|c|c|c|c|c|c|c|c|c|c|}
\hline \multicolumn{2}{|c|}{ 郝後日数 } & 4 & 7 & 10 & 14 & 17 & 21 & 30 & 60 & 90 \\
\hline \multirow{5}{*}{ 上 } & 正 & 一 & - & - & $m$ & \pm & + & + & + & + \\
\hline & 円柱上皮 & - & - & - & - & \pm & \pm & + & + & $t$ \\
\hline & 杯状緗胞 & - & - & \pm & \pm & \pm & \pm & + & + & + \\
\hline & 立方上皮 & - & - & + & \pm & $t$ & + & $t$ & \pm & \pm \\
\hline & 榊平上皮 & - & \pm & + & + & + & + & \pm & - & \pm \\
\hline \multirow[t]{2}{*}{ 书 } & 脱 & $H$ & $H$ & \pm & + & - & $H$ & + & - & + \\
\hline & 再 & - & + & \pm & + & \pm & \pm & $H$ & $H$ & $H$ \\
\hline & 巨脂 傥 & \pm & + & + & + & + & + & + & + & + \\
\hline \multicolumn{2}{|r|}{ 維 化 } & - & \pm & + & + & + & $H$ & $H$ & $H$ & $H$ \\
\hline \multirow[t]{2}{*}{ fin } & 張 & - & \pm & \pm & \pm & + & + & $H$ & \pm & + \\
\hline & 颗 & \pm & \pm & \pm & + & H & H & $H$ & H & $H$ \\
\hline 管 & 球 & \pm & \pm & \pm & + & + & H & $H$ & $H$ & $H$ \\
\hline \multicolumn{2}{|c|}{ 腺 } & - & - & - & - & - & - & + & + & + \\
\hline \multicolumn{2}{|c|}{ 彩胞唚 潤 } & $H$ & + & + & + & + & + & \pm & \pm & \pm \\
\hline \multicolumn{2}{|c|}{ 肉等 增生 } & \pm & + & + & \pm & \pm & $H$ & + & \pm & + \\
\hline 浖 & 朠 & $H$ & $H$ & + & \pm & \pm & \pm & + & \pm & - \\
\hline \multicolumn{2}{|c|}{ 壊 } & $H$ & + & + & \pm & \pm & \pm & - & - & - \\
\hline & 収 & + & + & + & \pm & $T$ & + & + & \pm & + \\
\hline & 䉼生 & - & - & - & + & \pm & + & + & + & $t$ \\
\hline
\end{tabular}

(一) 企く罗られ好。の

（土）一部に見ら机るもの(あるい愢度のもの）

（十）大部分に見られるもの（あるいは中等度のも D)

（H）覒しいもの（あるいは高度のもの）

る。粘膜下層は出血，躴死，浮堙，炎性細胞浸潤が著明

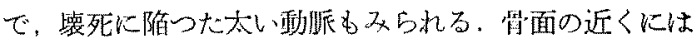
毛細管の新生を認めるが固有䅉内には余りない，骨は吸 收像を見るものもあり，その部から移植片への毛細管の 侵入及び線維芽細胞の出現がスられる。腺は全く認めら れない。

第 I群（術後7日目）

一部に凝血塊もあるが，移植片の中央部に扁平化した 上皮の出显を認める。自然口付近に残存した上颚洞粘膜 との接合部では杯細胞をるつ線毛円柱上皮があり，移植 片へ移行与るに従い、次第に高さを減し，立方上皮から屚 平上上皮に移行し，線毛及び杯細胞はない，中央部では上 皮を欠き基宣膜が露出している部分もある，腺は全くな

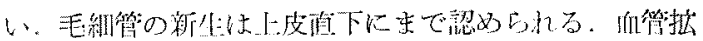

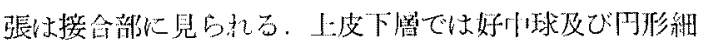
胞浸潤は急速に減少して線維化が現加孔ている。 
掵鸟 群（術後10日日）

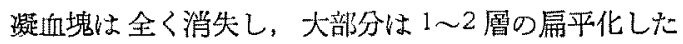
上皮に㠅われる，極く一部には杯緗胞を含む円柱上皮子 みられるが線毛はない，残存粘膜との接合部は線毛円柱

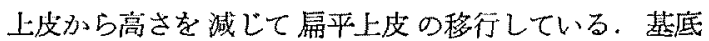
膜はよく認めら机る。上皮下層の線維化はやや強くな る.血管は余り多くないが㹡張して括り，内空の血球は 少い，腺性全々認女ら北ない，骨恃所及吸収さ礼消失 し，その部には結合織の增殖がある，浮睡は高度であ る.

第田群（術後14日目）

上皮は2 3 層の扁平上皮で，一部に立方上皮から線 毛円柱上皮への移行がみられる. 円柱上皮の部分には杯 細胞も少数ながらみられる。基底膜は明瞭である。上皮 下層には血管の拨張，新生が目立ち，内腔の血球は增加 している。線維化は【群上り高度である，浸潤細胞は 少数の好中球, 円形細胞で線維芽細胞の增生もむり線維 化の進行を思わせる。浮腫は軽度である，骨には吸収， 不規則性堌殖のみられるものがあり，骨欠損部には円形 細胞浸潤が著しい これは移植片部の炎症が固有鼻腔側 へ波及したためと思われる，肉芽組織の晴殖した部分は 上皮を欠くがその周辺部は残存粘膜からの新生屚平上皮 で覆われている。

第田'群(術後17日目)

上皮は第四群の如く2 3 層の扁平上皮が 大部分で， 移植片の辺縁部の線毛円柱上皮及び高岂を減じて扁平上 皮へ移行する部では杯細胞が增加している，所々にみら 机る肉莱組織增生部で上上皮を欠く。粘膜下層好線維化 が高度で血管の脑張，新生像をみるが，内腔の血球け多 くない，腺は全くみられないが，一部上皮が上皮下層に 入り込んで腺形成のよらな所見がるられる。

第 $\mathbb{N}$ 群（術後21日目）

上皮の大部分は2 3 圈の屚平上皮で，円柱上皮は辺 縁部に極くわずか認められるに過きない、粘償下層の線 維化は增強し，骨との結合が強固となつている，佂管の 增加は著明でなく，血球も少い，刘沁部の鼠腔僛壁粘膜

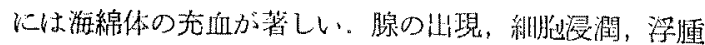

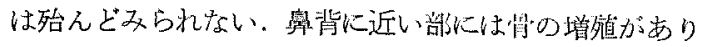
不規則化している。

第 V群（術後30日目)

上皮は大部分線毛円柱上皮となり，その高さも正常の

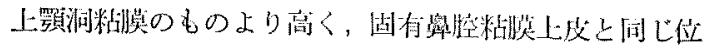
となる，杯細胞も增加し，固有舆腔粘膜にみられると同
程度のところもある。一部には依然扁平上皮の部もあ り，残存粘膜との接合部には，第四'，IN群に見られたよ らに線毛円柱上皮から扁平上皮に移行している例むあ る。基底膜は明瞭である，上皮下層の線維化は一層高度 となつている，血管は動静脈共その数を增し，执器は溞 く，管腔内の血球も增加している。この群では I〜N 群 に見られなかつた上皮下層内の腺を少数ながら認める。 その細胞質は H・E 染色で暗調比染色され，マロリ一染 色では赤染され，粘液性分泌物の貯留を認める，骨の新 生像も著明なものがあり，随所任血管が貫通し，骨䯘の 形成もみら机る，対応する固有鼾腔粘膜にも血管の推張 がある. 即ち固有鼻腔と移植片間の血管の連絡を物語つ ている.

第 V群（術後60日目）

5 例中3 例は背の高い線毛円柱上皮に㽝われ，杯細胞 は增加し，舆腔粘膜上り遥加炕多い。所么に intraepitheliale Drüsen の形成が見られる。基底膜は明膯であ る.上皮直下には多数の太い動静脈の新生があり，血球 も多い，腺も增加し，その周用には毛細管の新生が多

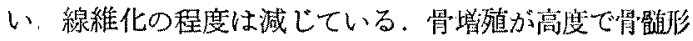
成のみら礼るものもある。

第训群（術後90日目)

上皮は活添完全な線毛円柱上皮となり，紐胞の配列は 密で，杯細胞の数はり群上り減少している，基底膜は明 瞭で PAS 染色でやゃ兴化している，上皮下層の線維化 は治群に似ている，边管はり群より增加し，管内の血球

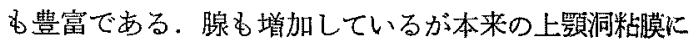
特けるよりも少い，緗胞浸潤は極く軽度で浮腫も殆儿ど 見られない，骨の增殖はり群之同程度で新生の做问はな い，一部に異所性歌骨の新生がある。

3) 胘中隔の粘膜採取部位の修復 観察結果の大要を表 (3) 飞示す 第 I群 (術後 4 日目)

上皮は線毛円柱上皮召ら急激に高さを減して扁平上皮 となり露出した歌骨面に延びている，軟骨面は大部分簬

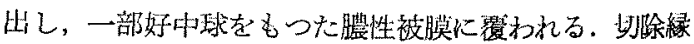
には炎性細胞浸潤があり，毛細管の新生，線維化が始る つている.

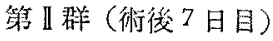

辺縁部で円柱上皮から移行した扁平上皮は 1 群より延

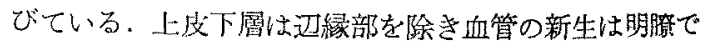

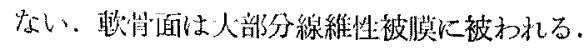

第 11 䧳（術後 10 日目） 
表 3 中隔粘膜採取部の組織学的所見

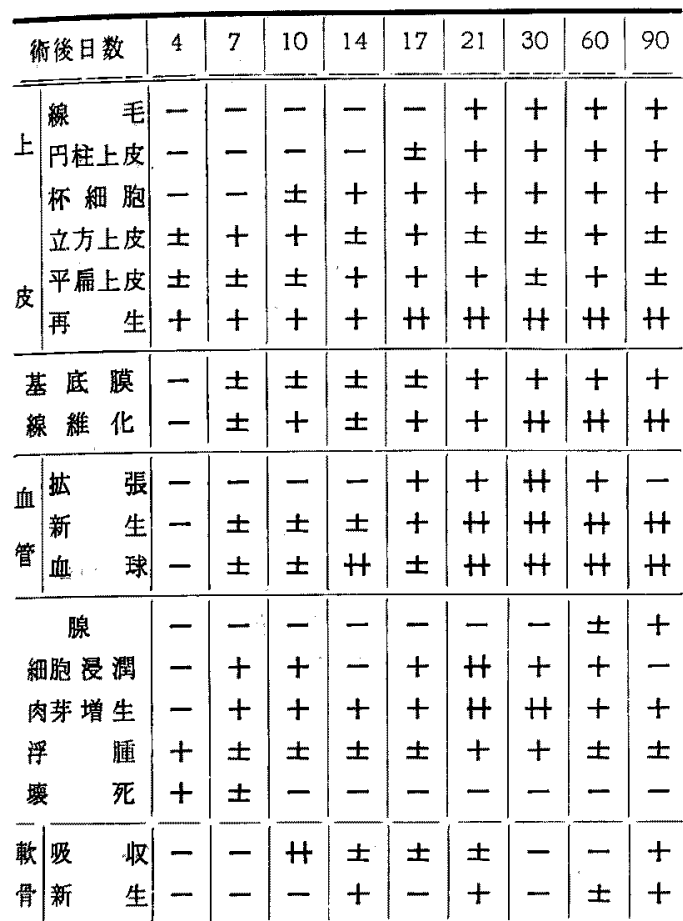

(一) 全く見られ奴田

（土）一部に見られるむの（あるい柽度のむの）

（十）大部分に晃られるもの（あるいは中等度のも の)

（H）著しいるの（あるいは高度のるの）

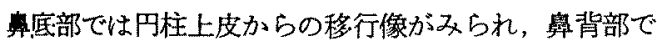
は肉芽組織の增生があり，中央部は上皮を欠き，線維性 被膜のみに覆われている．基底膜は再生部の先端では不 明瞭であるが，基部では菲薄ながら認められる。上皮下 層の線維化は更に進んでいるが，部分的にはな括浮腫を 呈している. 毛細衈管の新生がみられる.

第目群 (術後 14 日目)

哌平な新生上皮は大部延びているが未だ全面を覆らに は至らない：上皮下層の線維化が著しい，鼻背部に近く 增生した肉芽組裁では血管の㹡張が目立ち多数の血球を

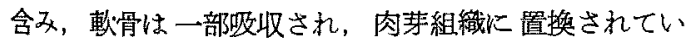
万.

\section{第四群(術後 17 日目)}

上皮の再生は更に進み，密に線維化した結合織の上に 延びているが未だ中央部では上皮を欠く，再生上皮の基 部で沬上皮細胞は円柱上皮で少数の杯細胞を混じ線毛を 琹めるが，尖端部に行くにつれ次第に高さを減じ屚平化
している．上皮下暞には拉張した新生血管がある，腺は 全くみられない，穿背部に近い肉芽組織心線維化し，そ の部の血管㹡張は著しくない、上皮化された部及び肉芽 組織の部に整骨が吸収され，結合織に置換された像があ り，一部には骨增殖がられる。

第N 群(術後21日目)

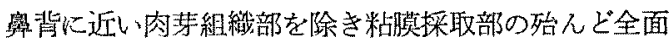
に線毛円柱上皮が再生し，杯細胞も出現している。しか し上皮の高さは不揃いで，一部には扁平上皮子みられ る、基底膜は明膫で，上皮下層の 血管怔目'群より增加 し，内腔の血球も增加している，再生部の基部では腺の みられるものもある。歌骨と上皮下層の間には明瞭な軟 骨膜を欠き貼骨との境界が不鮮明で，軟骨から直接に上 皮下圈に移行しているよ5に見える。

第 V群 (術後30日目)

上皮の丽生恬活完全に行われ，すべて円柱上皮で， 高さも，杯細胞の割合も正常舅中隔呼吸部上皮と変りな い.上皮下尿の線維化は更に逶又，血管の数もわずかな がら增加を見る。

第 V， VI群（術後60日，90日目）

再生上皮の所見及び上皮下層の線維化の状態むV群之 変りがない，腺は散在的であるが新生を見る。

4) 小括及び考接

上皮:

上顎洞内側壁に移植した骨中隔粘膜上皮は 4 日目では nekrobiotisch の状態で染色性にそしいが基底細胞は大 部分認められる．7日目に移植片の中心部に扁平化した 上皮が認められることは，上皮の再生が，移植片に保た れた基宣細胞から行われることを示している。移植片の 辺縁部に接して腺を多数にるつた線毛上皮に覆われた 粘膜があり，この上皮は移植片の方に延び，次第に高さ を減して移植粘膜上で消失している，恐らくこれは上顎 洞内に残存した粘膜が移䐈片と相接し，その部からも上 皮化が行われたものと考えられる所見である.14日目 では移植粘膜のは卧全面が上皮化されるが未だ殆儿どが 屚平上皮であつた，画生上皮が線毛上皮となるのは30 日目以後で，この頃には杯細胞も認められる，60日目 には杯細胞もその数を增し，上皮は鼻腔呼吸部粘膜に酷 似してくる。

苝中隔の粘膜採取部では 4日目に辺緑部の残存粘膜か ら扁平化した上皮が伸展し始め，17日目には欠損部の ほぼ全面が上皮化され，30日目に性線毛上皮となる。

上皮の再生に要する期間と丽生上皮の形態の推移に関 
しては移植粘膜と鼾中隔の再生粘膜の間には余り著しい 差はないように思方れる。

杯細胞については移植粘膜では 30 日目に，䊆中隔再 生粘膜では21 日目に出覞をみているが，60日目以後で は著しく增加し，その数は対炤の呼吸部上皮に匹敵し， intraepitheliale Drüsen の形成む見られる。 又一部に は腺の形成を思就る上皮の陌入も認められる。

基 底 膜:

移植片では移植直後の上皮及び固有層に nekrobiotisch な変化の強い時期にも PAS 染色，鍍銀染色て大 部分に基底膜を認め，移植のような強い侵裝に対しても よく抵抗し存在することが分つた，以後経過を追つても 特に著しい変化は見られなからた。

鼻中隔再生粘膜では辺緣から再生する上皮の先端に菲 薄ながら認められ，上皮の再生が進むと共に明瞭にな る。肉芽組織少增生し，仲々上皮化されない部で就め られない，再生上皮が線毛上皮となれば対照の鼻粘膜上 皮と同様に明瞭に認められるが，著明な肥厚はみられな かった.

血 管:

移植粘膜に㸵ける血管の新生以移植㦿である上頻洞内 側の骨壁から起ることは想像に難くないが，4日目の組 織標本で一部にそれを思わせる所見が認められた，丰細 管の新生は7 日目に上皮直下にまで見られるが，この時 期には上靧洞内に残存した粘膜あるいは增生した肉芽組 織と移植片との接合部からも血管の新生が行われている と考えられ，この状態はラテックス注入標本で確かめら れた．比較的太い血管が見られるのは14日目からで， 以後次第にその数を增している，しかし血管内腔に多く の血球がみられるようになるのは21日目からで，血行 の增加を思わせる。微細血管の分布密度は組織標本では 把え難く、ラテックス注入標本でよく観察される。血管 壁自体の肥厚，炎症等の所見は余り見られなかつたが， 血管の摭張は 7 日目から見られ，30日目に最強であつ た.

鼻中隔では粘膜再生部の周囲に血管の㹡張がみられ， 未だ一部上皮化が完了していない17 日目では軟骨面を

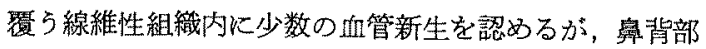
に近い肉苯組織内には多数の血管の新生がみられる。番 中隔の再生糊膜では，移植粘膜に比して各群の固有層は 薄く，血管子少い

上皮下層:

移稙片では 4 日目に高度の細胞湢潤があり，7日目に
は線維化が 現われ，21 日目以降では高度の線維化が認

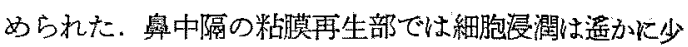
く, 線維化は上皮化された部分に強い観があり，上皮化 が全面に及んだ 21 日目に拁いては上皮下層の線維化は かなり高度である，鼻中隔の再生粘膜と移植粘膜の上皮 下層を比较すると，移植粘膜は 2〜3 倍の厚さをるっ. 細胞間質の浮㬭は移植粘膜に強く，10日目本で高度 であるが線維化の進行と共に筬ずる。

腺:

移粗粘膜では 4 日目には腺は認められず，腺細胞は之 血，炎症等住対して抵抗の弱いことが考克られ，多くの 㘧告にある如く萎縮性學炎で腺の娍少，萎縮，变性等の 生ずる原因の一つKも同様の機序が想像される.上皮が 線毛上皮となる 30 日目に少数の腺が出現し, 以後次第 そその数を增すが，90日目でも舅粘膜嗅部，呼吸部门 比し遥かに少く，本来の上頡洞粘膜より少い，又 $\mathrm{H} \cdot \mathrm{E}$ 染色では暗調に染色され，呼吸部及び上颚洞粘膜に見ら れる腺に類似し，移植粘膜に移植前にあった䫝腺とは翼 る. マロリ一染色ではアゾカルミンの色をとつて腺細胞 の内腔が杯細胞の如く赤く染まるのが目立つ. 即ち粘液 を産生している。

祭中隔の粘膜再生部で出腺の再生は移植片より遅れ， 60 日目から文られ，午の数も少小。腺の種類は移植片 と同㥞である。

骨・軟骨：

移植床である上顠洞内側壁の骨は極めて薄い、表面平滑 な骨板で，個々の家农で特に著しい差異は認めなから た，移植後に和ける骨の変化は区々で，骨が消失して移 植粘膜と奥腔側壁粘膜が骨膜を境に相接しているような むのから上顎洞側に不規則に增殖し肥厚した部に骨䑾が 形成されているもの，又一部軟骨形成のみられるもの むある。

鼻中隔の粘膜採取部でも採取側に軟骨の不規則な增殖 のあるもの，逆に軟骨が消失して削り取られたよらなる のまであり，骨・軟骨の变化を術後日数を追つて整理す るのは困難である。

\section{2. ラテックス注入標本}
1) 対
照

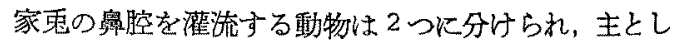
て外頸動脈から一部は内頸動脈からの血流を受けてい る.外頸動脈からは翼口蓋䡃脈が出て楔状口蓋㲜脈及び 眼窝下動脈となる．前者は奥腔側壁を通つて前甲介，上 顎洞，奥中隔に分枝し，節骨動脈と吻合する，後者は顔 
面に出る前に鼻腔，上颣洞をらるおす，内頸動脈からは

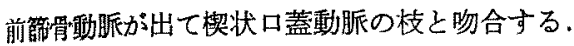

賈粘膜の血管は浅層に毛細管，深㬝に比較的太い血管 がみられ，動静脈については Swindle (1937) の云う ように浅層が静脈，深層に動脈のみられる V/A 形態を 示している。

中温及び側暨の後部は小動静脈が多く，浅層の毛細 管絧の形成は比較的少ない，中部では動静脈が少くな $\eta$ ，毛細管網の形成が增加し，前部ではこの傾向は更に 強く，毛細管網の形成は密になる。上颚洞では血管が細 く，少く，分布る鼼中隔，側壁に見られるより平面的で ある。

血管壁は全般的に平滑で，著しい蛇行，扰張，狭䆟等 の所見は見られない。

各部の計測結果は表 4 の通りで，絧限数小中隔前部が 最多で 195，次いで側壁前部の149で毛絸管網の密なる ことを示して扣り，中隔後部では 86，溉壁後部では72，

表 4 鼻粘膜各部の計测檤

対 照 群

\begin{tabular}{|c|c|c|c|c|c|}
\hline 部 & & 位 & 網 腿 数 & 網根の大きさ & 管径 \\
\hline 置 & 前 & & 195 & $60.6 \times 45.6 \mu$ & $16.1 \mu$ \\
\hline 中 & 中 & 部 & 111 & $92.4 \times 41.8$ & 23.6 \\
\hline 愞 & 後 & 部 & 86 & $118.0 \times 68.4$ & 26.9 \\
\hline \multirow[t]{2}{*}{ 㑡 } & & 部 & 149 & $72.2 \times 47.6$ & 20.9 \\
\hline & 中 & & 120 & $81.8 \times 42.6$ & 19.6 \\
\hline 壁 & 後 & 部 & 72 & $116.1 \times 64.2$ & 24.6 \\
\hline & 顎 & 洞 & 81 & $116.4 \times 66.4$ & 12.0 \\
\hline
\end{tabular}

絧腿数は $0.85 \mathrm{~mm}^{2}$ 当りの数

上顠洞では 81 で毛細管網が 眯である，網腿の直径はこ れとほぼ逆比例の関係で中隔前部で恃長径 $60.6 \mu$, 短烽 $45.6 \mu$ ，側壁後部では長径 $116.1 \mu$ ，短径 $64.3 \mu$ ，上頻洞で は長径 $116.4 \mu$ ，短径 $66.4 \mu$ である。毛細動脈む悬腔で は $20 \mu$ 前後であるに比し，上頻洞では $12 \mu$ と細くなつ ている.

2) 小括及び考按

重糊膜の微細血管分布については Swindle，Dawes 等 (1953) が家鬼, 犬等を用いて観察しているが，各部 位別のすのではない，本邦では作藤が猫で墨汁を注入，

河野が家象でラテックスを用いて詳しく観察している.

著者む河野の方法によつた．正常家香についての観察結 果住表 4 の如くでよく河野の成續と一致した．このよう
に安定した成績の得られるラテックス注入法は奥粘膜の 微細血管の観察には優れた方法であると考学られる。

3）移植片のラテックスに上る血管像

ラテックス注入群の家重を表 1 亿示した如く術後日数 により 7 群に分け，主要な所見を表 5 に示し，各群に特 徵的な所見を順以記述する，移植片では動，静脈の区別 が他の與粘膜に打けるようには判然とせず，又走行が不 規則である。

表 5 移植料膜の所見（ラテックス注入洣）

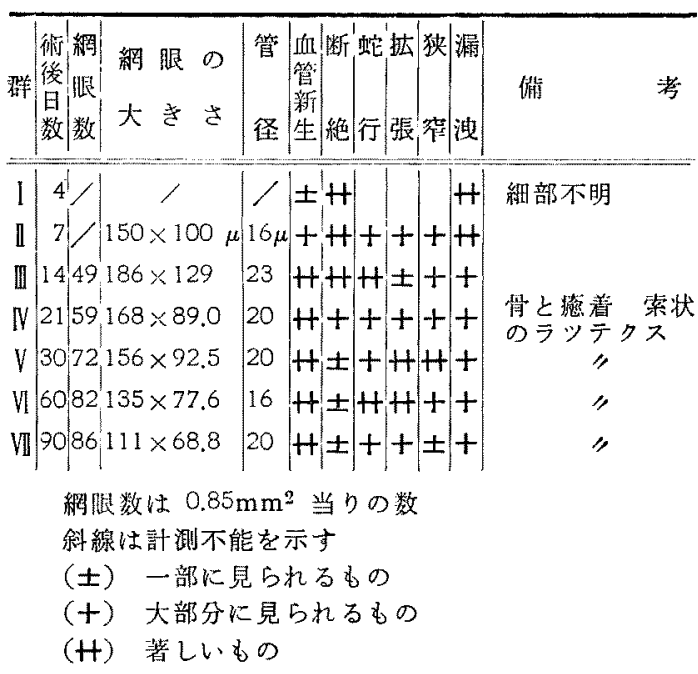

第 I群(術徭 4 日目)

移植片全体にラテックスの漏洩がつよく，殆んど血管 の走行は認められないが，極く一部代 $25 \mu$ 前後の細い 血管が見られる。網眼の形成はみられない，移植片の剝 離に際し骨面との癒着は著しくなく, 又周囲上り移植片 と交通する太い血管も見られなかつた。

第 群(術後7日目)

ラテックスの漏洩は传然広範围に及び，血管の認めら れる部分は少いが，断絶した太い血管にラテックスが充 満している像や，血管が新生して網眼を形成している像 子見られる。その網眼は棈円形あるいは不正多角形で, 長径 $150 \mu$ ，短径 $100 \mu$ 前後のものが多い，網状毛細管 の直径は細く $16 \mu$ 前後であるが，単位面積当りの網眼 数を問題にし得る程には網眼形成は完全でない，

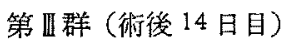

前群で見られた断絶した太い血管は見られず，自然口 より移植片と交通する太い血管のみられるものがある。 移植片には最大 $80 \mu$ にも達する血管の新生像があり， 
あるものはその末端が急激に細くなり，消失したりその 㩇の太さで急に断絶しているところもみられ，全般に不 規則に蛇行している。浅㢞，深層共にこのよらな血管が あり，他の鼻粘膜部に見られる浅層は毛細管網，深層は 比較的太い毛細動静脈といら規則性も乱れている，毛細 管網の形成は随所に見られるよらになり，その形は不正 多角形で計測値の平约は長径 $186 \mu$ ，短径 $129 \mu$ であり， 網眼数は49であつた．ラテックスの漏㖂はこの群では 著しく減少している。

\section{第 $\sqrt{ }$ 群（術後 21 日目）}

内径 $95 \mu$ 前後の比較的太い血管が樹枝状に新生し， 搪張，狭窄，蛇行が見られ，更に細い血管汇分れ，網眼 を形成している，乙の数は59，長径 $168 \mu$ ，短径 $89 \mu$ と 前群に比しその数を增し，大きさを減じている．移植片 と骨との癒着は高度になる。

第り群（術後30日目）

移植片と骨との癒着は高度となり，剝離は困難で，剥 離にさいし骨と交通する血管と思われる数条の細い索状 のラテックスを切断した．此較的太い血管性その内径が $85 \mu$ 前群儿比し細くなつているがその数は增加してい

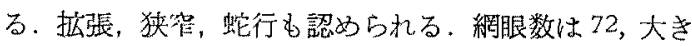
さは長径 $156 \mu$ ，短径 $92.5 \mu$ と前群よりその数を增し， 大きさを減じている。

第训群 (術後60日目)

移㥀片々骨之の㾤着は前群と同様高度である，血管の 扰張、蛇行，狭寉は本群でもかなり強く、ラテックスの

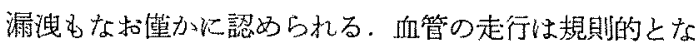
り，太い船管は深層を，毛細船管は浅圈を起る傾向が認 められる，絧眼数は 82 と增加し，長径 $135 \mu$, 短径 77.6 $\mu$ と小さくならている.

第䧃群(術後90日目)

移植片の剝離汇際しての㧧着は高度で骨から流入する 雲状のラテックスも数を增している，自然口から移檩片 に至る血管も太く，内径 $450 \mu$ に達するあのもある。こ の血管上り分枝する血管も太いもので $100 \mu$ 前後のも のもある、この群でも太い血管は樑層に，毛細血管は浅 層にみられる。網腿数は86, 長径 $111 \mu$, 短径 $68.8 \mu$ と なっている.

4) 小括及び考掞

術後4日目では移植片全体にラテックスの漏洩が強 く，血管系の再生は未梧めて嚾か炕見られるに過ぎな いと考学られる、組織像で出血，壤死等がみられ血管が 殆えど見られない所見と一致する。
7 日目ではな批漏洝は強いが一方網眼形成も見られ， 移植片の血夜㴶流が一部で行われる上らになつたものと 考えられる. 組織所見では炎症像が相当強く見られる之 ころから、ラテックスの漏洩の強いことも肯ける。

14 日目で自然口から移植片に流入している太い血管 のみられることは自然口からの血液供給路の成立を示寸 所見で, 移植片内の血管新生像と共倸植片の上顎洞一 の定着と考克られる，又組織像でも自然口の粘谟より移 植片への糊莫の連続的な再生像を見ている。

21 日目に索状のラテックスが骨面との間にみられた。 これは移植片が定着し，骨面からも血流をらけることの 証左ともなろう。剝離が困難なことは組織像で骨面との 線維性結合が強くなつている所見と符合する。

30 日目以後では毛細管網は日を追つて密となる，移 植片に供給される血液は自然口よりのるの，骨面よりの

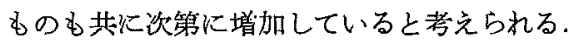

90 日目では毛細管網の数は86,大きさは長径 $111 \mu$, 短径 $68.8 \mu$, 毛細動脈の直径 $20 \mu$ となり，対照の上䫑洞 飞持ける網腿数 81 ，長径 $116.4 \mu$ ，短径 $66.4 \mu$, 管径 $20 \mu$ と似てくる，組織像では上皮については完成されてお。 り，血液供給の面から考光れば，上顎洞糊莫と同様とな っている.

な标 Tiedemann (1957/8), 白岩 (1959) 等の云う 動静脈昒合上思かれる所見は対照群では見られるものも あったが，移植粘膜には見られなからた。

\section{IV 総括及び考按}

粘膜の移植は粘膜欠損部の上皮化の促進や粘膜の容積 を增す目的等で各科領域で広く行われている。耳奥咽搌 科領域でもその例は多く，粘膜上皮の強い再生能力が各 種疾患の治療に利用されている，例えば久保式上䫑下甲 介整形手術や，慢性副楀腔炎手術の赤池法等，又遊離移 植としては石井等の突縮性鼻炎手術に上顎洞粘膜を朋い る方法や，北村の䃟頭部分切除後に舅中隔战膜を用いる 方法等である.

粘膜上皮の再生力は強く，粘膜を除去したのみで移植 を行わずにも再生が行わ机る，即ち副䙹腔炎手術により 粘膜を除去した場合がその好例で Tonndorf (1928), Gorham (1930), Kistner (1931), McGregor (1931), 跉木 (1932)，本鄉 (1958)，青木 (1961) 等多数の報告 がある。

動物害験では粘膜移植の実験はそれ程多くはないが， 松田等（1956）は家乘の奥中㢳粘膜を上须洞に移植し， 移植片の化膿がない限り移淔は成功すると述へ，友田 
（1957）は術後性頓部壁愿の成因を研究するため家東で 身中隔粘谟を大腿部に移㥀し，約 1 週後に移植床に生着 することを認めている。

粘膜を除士したのみの例では Knowlton (1928) が犬 の上顎洞で Coats (1930), Hilding (1933) が犬の前頭 洞で夫々粘膜の再生を钼察し，Boling (1935) は羊の 番粘膜上皮を抒破してその需生像を，又 Greenberg （1962）は犬の気管粘膜の再生を钼察している，又腐玲 性薬物による粘膜損賃の動物実験もGrossmann (1922)， Burian（1958)，市川 (1964) 等により報告されている.

上記の笑験で使用された動物は犬，家鬼，羊等種々で あるが，本奏験には粘膜移植及び整流実験に利用できる 動物として比較的適当な大ささをもち，同一条件で飼育 与ることの便，入手の容易さ，又先に述へたた如く，自律 神絽に対する影響加少く，血管の研“究に適する麻酔用り レタンを用い得ること等を考葸して家東を用いた。

人では粘膜移植には上顎洞粘模が多く使われるが，正 常家鬼の上顎洞粘膜は極めて菲薄で，移植片乞しての利 用怡えと不可能に近く，たと之成功しても手術操作に よる損傷が甚しく本実験の目的には不適当と考えられる ので，採取が比較的容易で損傷のおそれの少い翼中帛粘 膜を使用した，又上顛洞への移植は術後前壁から侵入す る肉䨿組織により移植片が呢収され，上顎洞が肉莱組緎 で充渾する事が多いので，肉茅組織の侵入を防止するた め前記の如くゴム片を使用し，10日目に除去した。こ れにより肉茅組織の侵入は防止しえたが，コム片による 異物反応が予想された。しかし本实験の結果から，ゴム 片搜入はそれ程重大な影響を与えなかつたよらである。

上皮:

線毛上皮の再生は，粘膜の变性の影響を受け鄚く，線 毛細胞や杯細腿に分化する潜在能力をもつ基底細胞の分 裂，分化によることは容易に想像されるが，Thanhoffer

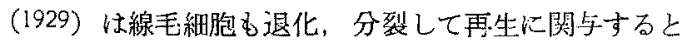
L，Bolingは羊の鼻粘膜上皮の再生老 4 段階に分け，

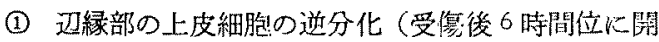
始)

(2) 逆分化した細胞の分裂及び移動に上る久損部の上 皮化

(3) 再生上皮の重層化

(4) 重層化した上皮細胞の再分化

とし，(2) の細胞分裂恃过縁でのみ行われ，欠損部の上 皮化は分裂によつて生した細胞の移動によつてのみ行わ れると述へている，本奏駼の移植片辺緣部，あるいは舆
中䧣粘摸画生部の所見は Boling の説と一致するが，一

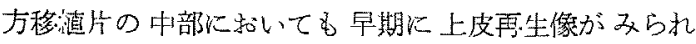

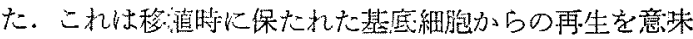
しよう。細胞の分列方式としては Grossmann, Hoffer は損傷の程度により間接分裂あるいは㨁接分裂を行らと し，Burian 等は DOCA 使用により聑生索促進された 上皮に然杀分裂による plasmodium の形成を垠告して いるが，著者の奏験では間接分裂のみのようであつた。

再生上皮の北態及び再生に要する期間は移植片で中中 村 (1957) は久保式整形手術施行例で 10 力月，15 力月 で多列線毛円柱上皮を認め，長野 (1963) は浾池法で移 植した上顎洞粘膜で 30〜50日で扁平上皮に化生し60〜 80日で線毛上皮となると述へ，動物では友田は家宽鼻

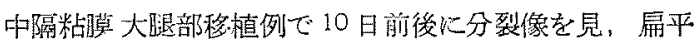

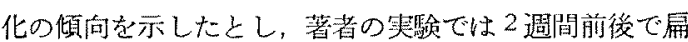
平化し，30日で線毛上皮となつた。

又粘膜除去部の再生についてみると，人の上頑洞で は，Tonndorf は2 週間後に扁平化した上皮の侵入を 認め，鈴木，青木は夫ヶ30日前後で扁平上皮となり， 60 日前後で線毛上皮となるとし，本郷は篩骨洞で 5 力 月で円柱上皮の完成をみたと報告している，動物では Knowltonは1 力月で線毛上皮を認め，著者の実験の鼻 中隔では2 週䦦で創面は牂平上皮で覆われ，30日で線 毛上皮になつた，又 Greenberg は犬の気管粘膜で 10 日で扇平化した上皮を，21日で線毛上皮を認めたと報

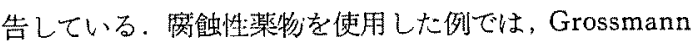
等はクロロホルムの贿入麻酔の動物気管粘膜で浅い上皮 欠損は遅くも3日で完全に修復されるとし，市川は家鬼 でホルマリンを用い，気管では10〜14日で，上咽頭で は4 调間で線毛上皮ができたと述べ，Burian 等は白不

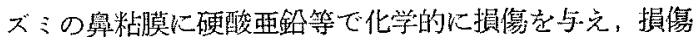
が深曆に及べば再生上皮は扁平上皮に化生し，表䁌の及 の易合には直接に線毛上皮が再生すると述へている。

本実験の移植粘膜で基底細胞は比較的よく保存され ていたにも拘らず線毛上皮の再生に30日を要した。 こ れは移植により血流が一時絶たれ，血管系の修復と其に 完全に再生されることを示している.

又術後の粘膜欠損部の治㾍過程に扣いては感染等が加 わつた場合，症痕組織が生し，上皮化されない例む報告 されている (Hilding, 名越)，本歨歌でも肉芽組織增生 の強い個所の上皮化には相当の日時を要した。

杯細胞け線毛細胞と同様に基底細胞を母細胞にるち， 種々の刺激時にその数を增し，刺激の消退と共に数を娍 
ずるとざれ (片山, Latta, Schall 等), 中村は老人性変 化に杯細蚫の增加を認めている．杯細胞と線毛細胞の 相互稌行については古来議論の多いところで，Latta， Schall（1934）は線毛細胞の粘液变性に上り杯細胞が生 じ得るとし, Sternberg (1924), Eggston (1947) 等は 両者の相互移行を認めている，又罳腺之杯紐胞の多宾は 代傎的関係にあるとも言和机，Knowlton は人では杯細 胞が多く，眿は少いが犬では逆に杯細胞が少く，腺が多 く，粘膜を除去した犬の上彭洞再生粘膜で荘未だ腺の再. 生の少い時期には杯細胞が多く，腺の增加と共儿杯細胞 法隇少すると述べている，杯細胞の增多の著しい時には intraepitheliale Drüsen の形成が見られるとされ Zarniko (1903), Schaffer, (1927), 欢 Messerklinger (1958) はピロカルピン注射によりモルモットの気管上 皮に intraepitheliale Drüsen の形成を見ている.

本実験の移植片では30日目に線毛細胞がみられるが， 60 日目には杯細胞の著しい增加があり，90日目ではや や隇少を示している. 線毛細胞との相互移行, 固有層の 腺の增加等との関係は興味ある問題である。

\section{基 㡺 膜:}

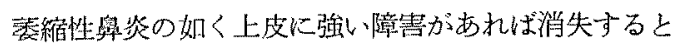
いわれ，中村は化生の認められる場所では消失するが， 化生のない場所では基底膜は認め得るとし, 北川 (1954) は鼾藏のPAS 染色で重層扁平上皮に化生した部で部位 により消失しているとしている. Braun-Falco (1959) は高度の肥厚性鼻资で基宣膜の高度の肥厚を報告してい る. Schumacher (1925) は表層の結合織層の硝子㚆性 に肥厚の原因を求め，中村は上皮の璣能殊に粘液産生能 力と基㡺膜の肥厚，消失は密接な関係ありとし，Messerklinger は抗原抗体反応による硝子様分質の沈着た と述べている.

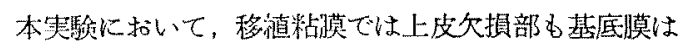
みられ，上皮の再生と共て明眿になつた。北川の言う如 く炎拝と基底膜の関釈の複雑さが想像される。

\section{血管:}

落縮性率炎に見られる血管の变化は，動脈内膜炎 (Schönemann 1902), 慢性 動脈周囲炎 (Lautenschläger) 閉鎖性䡃脈内膜炎（Ruskin 1932, Lautenschläger)，内膜の肥厚 (Krause 1881, Minkovsky 1931) 等々で中村の言う上うに通常の慢性楀炎に打いて子歴々 みられる所見であり，落縮性楀炎に特有なるのではない が，その变化の強さ，即ち血㖡供給不足をきたす度合が 重装であるら。
萎縮性鼻炎の原因の1つと考古られるるのK内分必の異 常があるが，登縮性鼻炎が女性に多く，思春期に発病す ることから oestrogen が注目され，Dorochenko(1937) 等は oestrogen を使用し萎縮性奥炎の治療に効果を認 め, Bernheimer (1940) 等は局所に 血管㹡張郕を使 用しても oestrogen と同様な効果ありとし, Harrison (1957) は oestrogen の長期大量投与は粘膜の扁平上皮 化を生じたと報告したが，Tailor (1961) は試験切除に よる損稘が原因であるとし， oestrogen の血管搪張作用 を強調している。 叉 Hollender (1944), Meserklinger は乾燥と血液供給不足を上皮化生の主な要素と見做し， Hilding (1932) は，犬，家束で片側の系腔を縫合し， 他側の奥腔に2 倍の呼吸を強制し，上皮化生を認めてい る.

本実験に扣いて，ラテックス注入梅本の示す血管系の 新生の極めて僅かな時期には上皮, 腺に退行的变化がつ よく，新生がやや進むと扁平化した上皮がみられ，血管 系の新生が更に進めば線毛上皮及び腺の再生が見られた ことは血管系と上皮, 腺の間汇密接な相関のあることを 示している.鼎中隔の粘膜再生部ではラテックス注入標 本による数量的観察は行わなかつたが，移植粘膜に比 し，血管の数も少く，網眼数も少い上うである.

腺:

Peter (1912), Wustrow（1959）は腺の発生は人では 娟生 4 力月頃に上皮の陥入により intraepithliale Drüsen の像を呈し，後に腺を形成すると述べ，Bolingは 動物実臨の再生粘膜で 同様の所見を報告している，Boling によれば羊の再生鼻粘膜の腺は30日目では極めて 少く，上皮細胞の線維化のために腺を形成すへき上皮の 陷入が妨げられるためとし, 僅が認められる腺は上皮 下層の線維化が末だ高度とならない初期㴼入した上皮 がその原器となると述べている。

本実験では30日自では未だ腺は少数で，intraepitheliale Drüsen の形成が目立ら，上皮の陥入による腺の 形成を思わせる所見があり，以後比較的深㬝の腺の数も 增加することから上皮下の線維化が高度であつてる上皮 の宿入による腺の形成はあり得ると考鬲ざるを得ない。

中村の指摘している如く, 腺は粘膜の生理機能の点か ら上皮，血管と共见最も重要な要素であり，再生粘膜の 完成の度合を知る一つの目標と考えられるが，90日目 の上频洞内の移植粘膜に扔いては腺は刘炤の呼吸部粘 膜より遥か儿少い，又この時期のラテックス注入標本に おける血管の所見がほぼ上䫇洞粘膜に匹敵している，腺 
と血管については移植90日日では本来の上教洞粘膜に 近くなる。乙かし上皮は呼吸部鼻粘膜に酷似しているの で，更に長期間の経過を観察すれば上頼洞内といら場で 上皮，血管，腺の3者の閻がいかなる組合世となるか與 味ある問題である，又，移植片に再生した腺は移植時に あつた烸液腺ではなく粘液腺であつたが，移植床である 上䅡洞に普通に見られるもので，移艋床の条件に対して の順応と考えるべきである。

\section{粘膜固有層：}

固有風の線維化は慢性炎症に通常見られるるので，勿

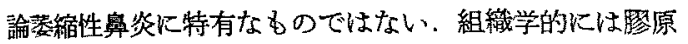
線維の增殖である。

粘膜欠損部の修復に当り, 結合織の增殖は古来病理学 総論の教えるところであり，移植粘膜でも赤池等は移植 片は強い線維化を示したと報告し，友田む固有尿の強い 線維化を認めている.一方中村は久保式整形手術では線 維化は比較的に弱いと述へている. 線維化の強さは移植 後の反応性资拝の弶さや, 移植片の血流状態左右され るものと思われる。

\section{骨，軟骨：}

骨及ひ軟骨のの変化は一定しない，恐らく使用した家象 の個々の体質，又移植手術時の操作に多少共不均一があ つたためと思われる。

Zöllner（1953）は外耳道皮虏弁を用いた亄室整形術 で，一部に骨の異所性增殖を認め，外耳道皮手の骨膜で はなく骨片が移植床に骨の增殖を促すのであるらと述へ ているが，本実験で見られた移植片内の異所性軟骨增殖 も移植片の軟骨膜に附着した軟骨片が原因となつている 可能性も考えられる.

\section{IV 結 論}

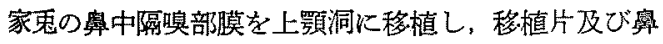
中隔の再生粘膜を組織学的に観察し，移植片については 更にラテックス注入標本で血管の状態を観察し，これを 正常家鬼と比較して次の結論を得た。

（1）奥中滆粘膜の上顎洞への移植山洞内八の肉芽組 较の侵入を防止すれば成功する。

（2）移植粘膜の上皮は移植粘膜上皮の基底細胞及び 周囲に残存した上刓洞粘膜上皮から再生され，14日で 扁平上皮，30日で線毛上皮となり，60日で上皮の再生 は完了する。再生完了上皮は奥腔上皮に酷似する.

（3）释中嗝の粘莫欠損部は辺緑部の上皮から再生が 㸝こり，21日で扁平上上皮に，30日で線毛上皮になる.

（4）稳植粘膜及び 舅中隔再生粘膜の腺は主として粘

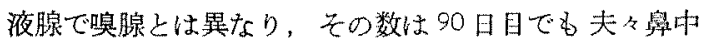
隔呼吸部粘膜に和けるよりる少い。

（5）ラテックス注入標本では移植粘膜に和ける血管 系は移植により一時荒廃するが，次第に骨面及び周照維 織から新生し，90日で本来の上顎洞の血管に匹敵する。

(6) 移植粘膜に和ける上皮，腺の再生は组管系の新 生し密接な相関を有する。

\section{䇣考文献}

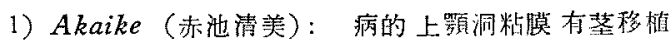
法，日耳雎，65：1403，1962（昭 37)。2)Aoki (清

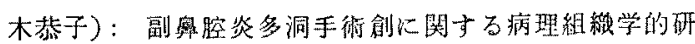
究，共済医報，10：9，1961（昭 36）。 3）Boling, R., $R$. Leroy: Regeneration of nasal mucosa. Arch. Otolaryng. 22: 689, 1935. $\quad$ 4) Braun Falco, F. Ueber die Basalmembran normaler und pathologisch veränderten Schleimhaut der oberen Luftwege. Z. Layng, usw. $38: 689,1959$. 5) Burian. K, et al.: Die Reaktion der Nasenschleimhaut auf lokaler Schädigung bei DOCA-und cortisonbehandelten Ratten. Mschr. Ohrehk. 92: 22, 1958.

6) Coats, GM. et al.: Regeneration of the mucous membrane of the frontal sinus, after its surgical removal (in the dog). Arch. Otolaryng. 12:642, 1930. 7) Dawes, J. $D . K$. et al.: Studies of the vascular arrangement of the nose. J. Anatom. 87: 311, 1953. 8) Doi (土 茾改息：肝藏の血管像及び血行飞ついて，扰萧の水医 誌, 4：701，1956 (昭 31).

9) Dorochenco, I.T.: Un nouveau principe de la thérapeutique de lózaène. Acta. Oto-laryng. $25: 524,1937$. 10) Eggston," A. "et al: Histology of nose and accessory sinuses, His:opathology of the ear, nose and throat. 53, 1947, Baltimore.

11) Fleischmann: Angeborene Schweissdrüsenmangel und Ozaena. $Z$. Laryng. usw. 20: 503, 1931. 12) Fränkel, E.: Pathologisch-anatomische Untersuchung über Ozaena. Virchow, Arch. $75: 45,1879 . \quad$ 13) Glas, E.: Ueber intraepithelie Drüsen, Cysten und Leukozytenhäufchen der menschlichen Nasenschleimhaut, Arch. Laryng. usw. 16:236, 1904. 14) Gorham, C.N. et al.: Regeneration of human maxillary antral lining. Arch. Otolaryng. 11: 763, 1930. 
15) Greenberg, S.D.: Regeneration of respiratory epithelium. Arch. Path. 73: 53, 1962.

16) Grossmann, B. et al.: Zur Regeneration des Trachealflimmerepithels. Zb. f. HNO. 1: 357, 1922. 17) Harrison, D.F.N.: Familiar haemorrhagic teleangiectasis, a survey of series of cases treated by oestrogen therapy. J. Laryng. etc. 71 : 577, 1957.

18) Hashimoto (橋本泰彦)：副奥腔の血管分布につ いて，耳㬋，28：827，1956 (昭 31). 19) Hilding,

A.: Experimental surgery of the nose. 1. Changes in the morphology of the epithelium following variations in ventilation. Arch. Otolaryng. 16:9, 1932. II. Gross results following the removal of the intersinus septum and strips of mucous membrane from the frontal sinus of the dog. Arch. Otolaryng. 17 : 321, 1933. III. Results following partial and complete removal of the lining mucous membrane from the frontal sinus of the dog. Arch Otolaryng. 22: 760, 1935. 20) Hollender, A. Histopathology of the nasal mucosa of the older persons. Arch. Otolaryng. 40:92, 1844. 21) Hon go (本楖裕)：病理組織学的に見た慢性篩骨蜂窝炎の手 術経過, 耳舅展㕵, 1:132, 1958 (昭 33). 22) Ichikawa (市川瑞雄他)：家乘舅咽腔炎の䟝離細胞学的业 びに病理組織学的研究, 日耳舆, 67:730, 1964 (昭39).

23) Ishii (石井英雄): 萎縮性楀炎の手術療法, 日耳 鼻，66：225，1963 (昭 38)。24) Katayama (片山

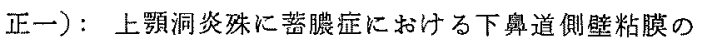
病理組織学的変化について，京府医大誌，4:475, 1930 (昭 5). 25) Kistner, F.B.: Histopathology and bacteriology of sinusitis with comments on postoperative repair. Arch. Otolaryng. 13:225, 1931. 26) Kitagawa (北川和男他)：楀革に战ける酸性多糖

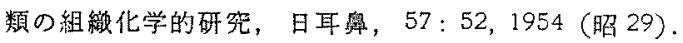

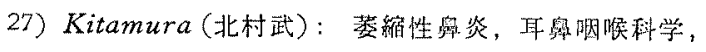
後藤敏郎, 上, 719,1960 (炤 35), 医学暂院.

Knowlton, C.D.: How and when the mucous membrane of the maxillary sinus regenerates. Arch. Otolaryng. 8: 647, 1928. 29) Kono (河野寿)：家

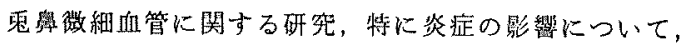
日奥耳，63：16，1960（昭 35). 30) Krause, H. Zwei Sektionsbefunde von reiner Ozaena. Virchow Arch. $85: 325,1881,31)$ Latta, J.S, et al.: The histology of the paranasal sinus under various conditions. Ann. Ot. etc. $43: 945,1934$. 32) Lautenschläger, A.: Die Rhinitis atrophicans. Hb. Halsusw. Heilk, von Denker-Kahler 2: 604, 1926, Berlin. 33) Marjorie, M. et al.: Arterio-venous anastomoses in the tongue of the dog, J. Anatom. 87:66, 1953.

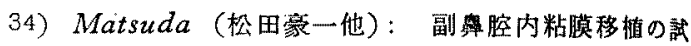
双，日耳翻，59：1141，1956（昭 31）. 35) McGregor, $G$ : Further proof of regeneration of mucous membrane in the human antrum. Arch. Otolaryng. 14: 309, 1931. 36) Messerklinger, W.: Physiologische und pathologische Veränderung des Nasenepithels. Arch. Ohr-usw. Hk. 165: 475, 1954. 37) Minkovsky, A.: Atrophie der oberen Luftwege. Acta oto-layng. 16:525, 1931。 38) Nagano (長野

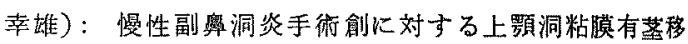
植，(赤池法)下括ける組織学的観察，日耳身，66:301， 1963 (昭 38). 39) Nagoshi (名越好古): 副举空 炎手術後の治瘾機轱之その障害について，耳喛，36: 977，1964 (昭 39)。 40) Nakamura (中村信成):

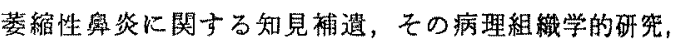
千葉医会誌，33：82，1957 (昭 32)。 41) Nishima$r u$ (西丸和羡)：体液循璝の研究，63，1952 (昭27)， 医学書院. 42) Peter, K.* Entwicklung der $\mathrm{Na}^{-}$ senmuscheln bei Menschen und Säugtieren. Arch. mikro. Anat. 80:478, $1912 . \quad$ 43) Ruskin, I.L. A differential diagnosis and therapy of atrophic rhinitis and ozaena. Arch. Otolaryng. 15: 222, 1932 ,

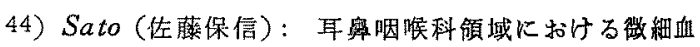

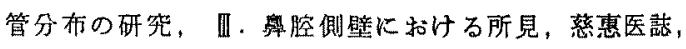
66：175，1952 (昭 27). 45) Schaffer, J.: Spezi. fität der Becherzellen. Hb. der mikro, Anatom. de Menschen v. Möllendorf 2: 115, 1927, Berlin. 46) Schönemann, A.: Die Umwandlung" (Metaplasie) des Cylinderepithels zu Plattenepithel in der Nasenhöhle des Menschen und ihre Bedeutung für die Aetiologie der Ozaena. Arch. path. Anatom. u. Physiol. 168: 22, 1902. 47) Schumacher, S.: Histologie der Luftwege und der Mundhöhle. Hb. Hals-usw. Heilk. von Denker-Kahler 1. 277, 1925, Berlin. 48) Semenov, et al.: Repair in the paranasal sinuses of man following removal of the mucous lining. Proc, Soc. Exper. Biol. \& Med. 27: 


\section{野口論 交付図 (I)}

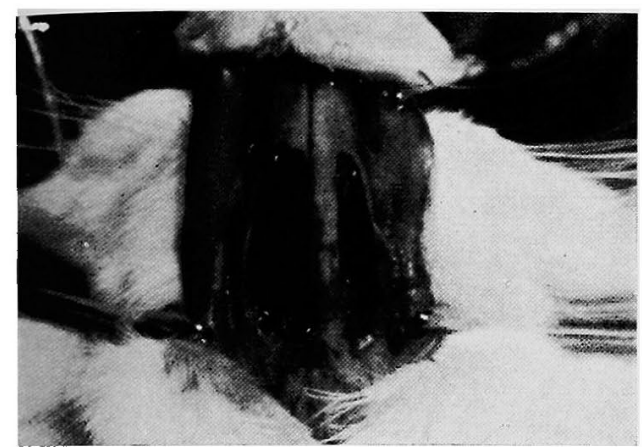

第 1 图移植手術移植前

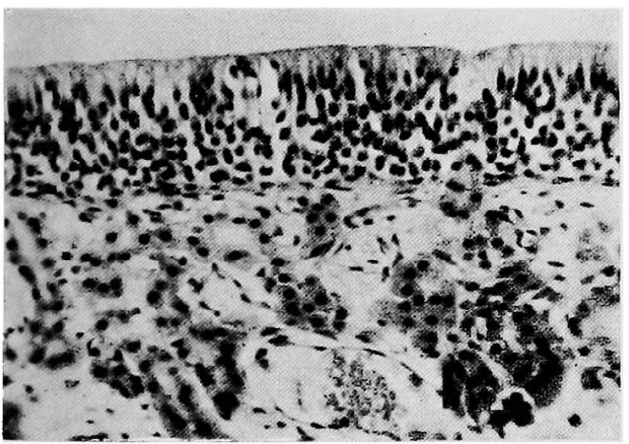

第 3 図鼻中隔嗅部粘膜 (移植片) HE. 強拻

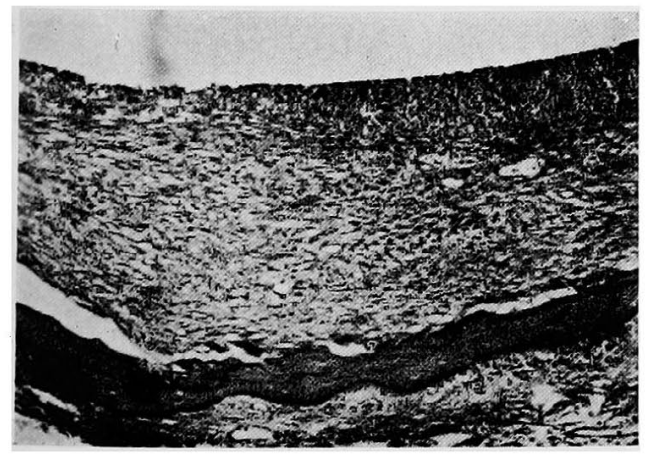

第5国 4 日目，移植片，上皮は nekrobiotisch. 固有㬝に強い細胞浸潤, PAS. 弱拡

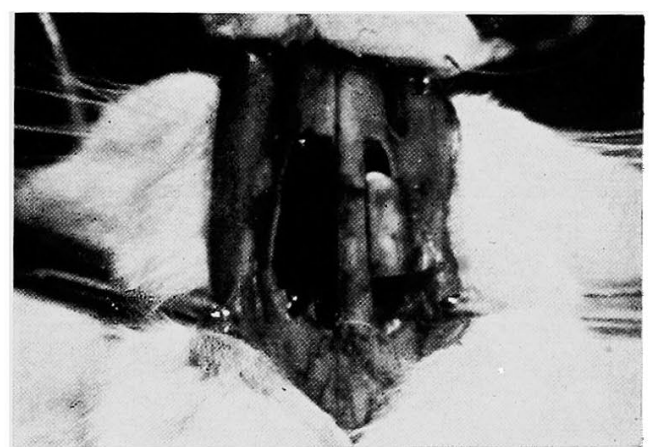

第 2 図移植手術移植完了

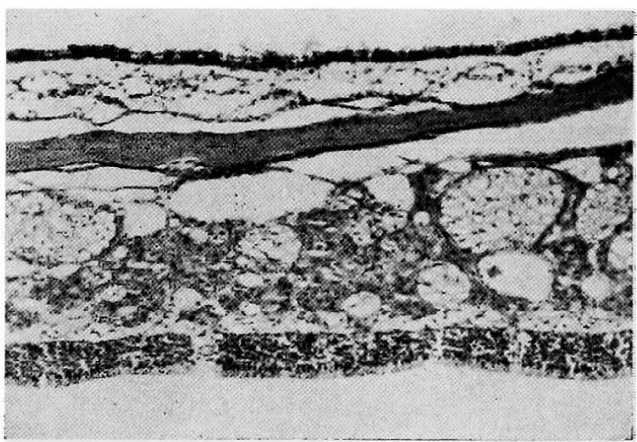

第 4 図上顎洞粘膜 (上), 鼻腔側壁嗅部粘膜 （下） HE. 弱扗

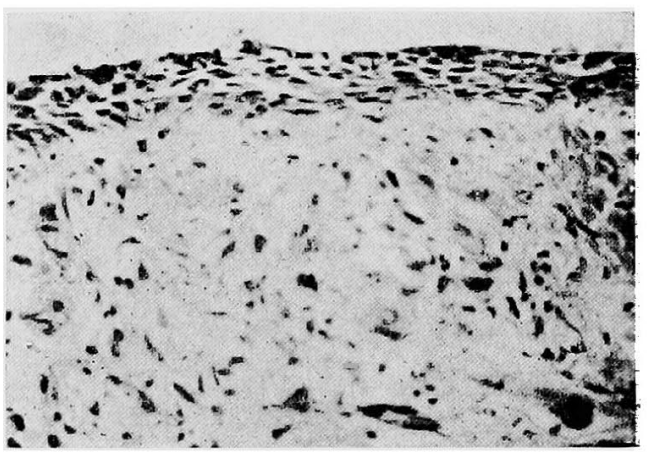

第 6 図 7 日目, 移植片中部, 基底細胞よりの上 皮再生を思わせる像, $\mathrm{HE}$. 強拻 


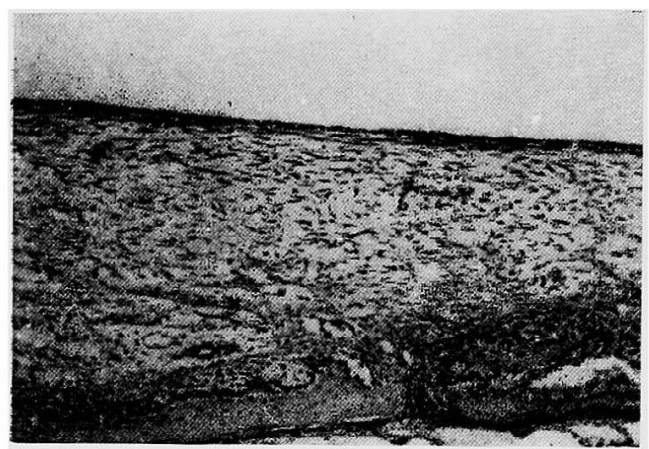

第 7 図 14 日目, 移植片（上），上皮は扁平化， HE. 弱拡

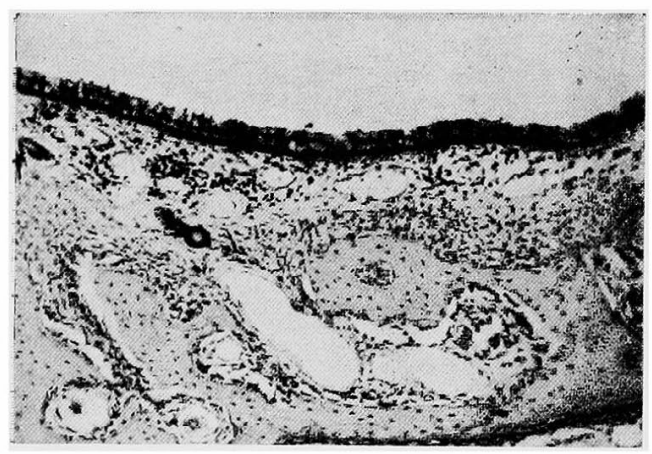

第9图30日目，移植片（上）円柱上皮となる. 上皮下層に腺の出現. $\mathrm{HE}$. 弱抎

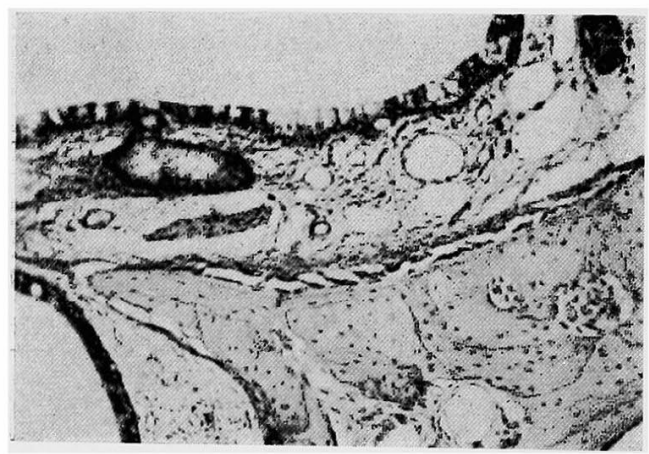

第11図60日目，移植片，上皮は円柱上皮，杯 細胞の增加. HE. 弱払

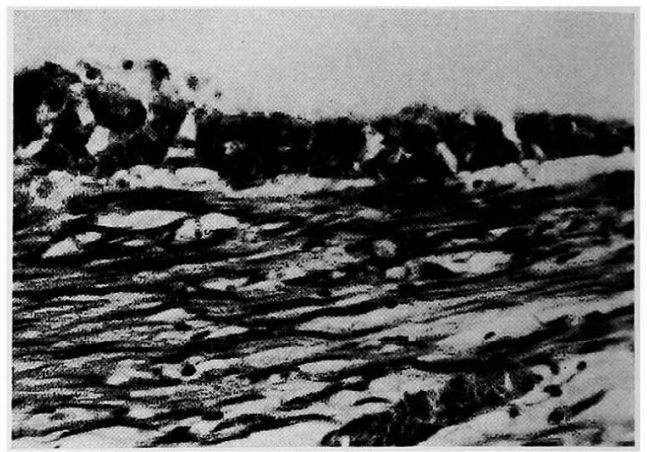

第 8 図 21 日目，移植片，一部に円柱上皮がみ られる.上皮下層の強い線維化, $\mathrm{HE}$. 強拡

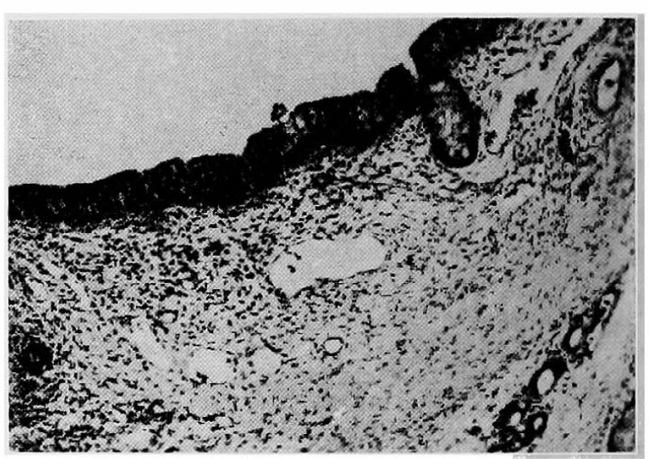

第 10 図30日目, 䔟植片, 上皮の陥入による腺 形成. 左方は肉芽增生. HE. 弱拡

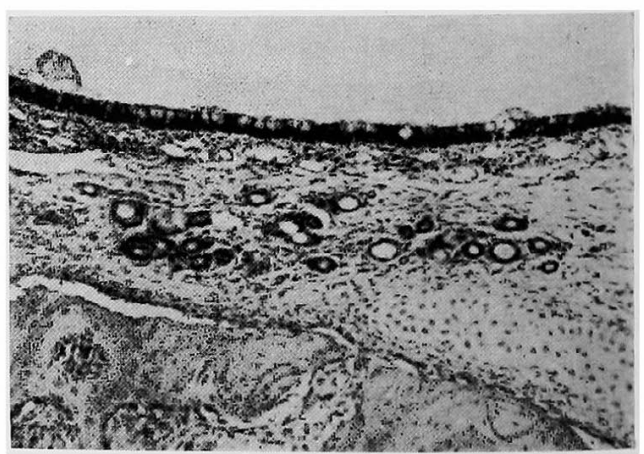

第 12 図90日目, 移植片, 円柱上皮, 腺, 骨增 殖がみられる. HE. 弱拡 


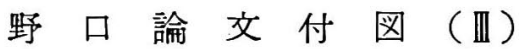

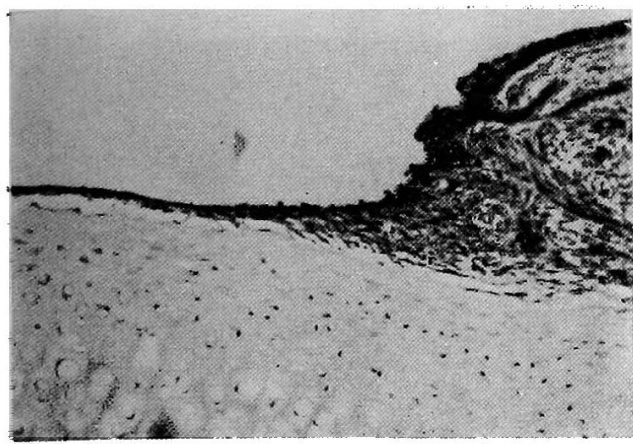

第 13 図 4 日目, 鼻中隔粘膜採取部, 切除縁か ら扁平化した上皮の伸展, HE. 弱拡

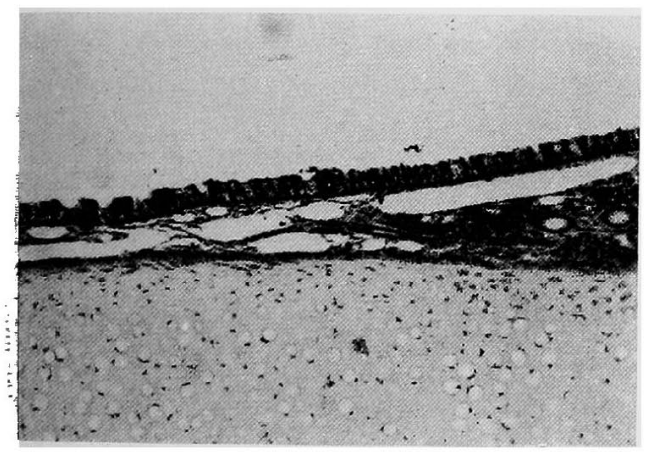

第 15 图30 日目，鼾中隔粘膜採取部，上皮は円 柱上皮となる. HE. 弱拆

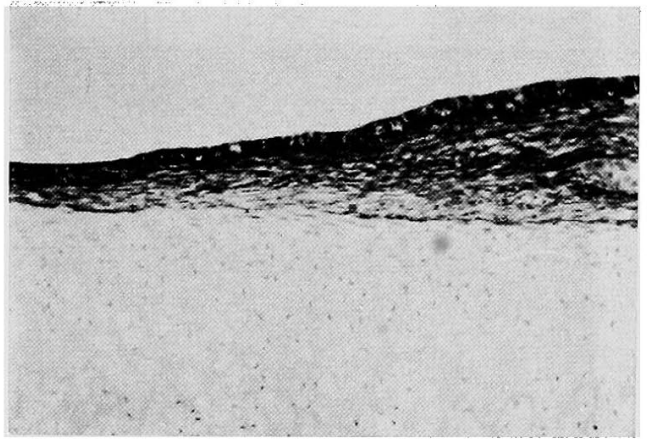

第 14 図 14 日目，鼻中隔粘膜採取部，上皮下の 線維化, $\mathrm{HE}$. 弱拡

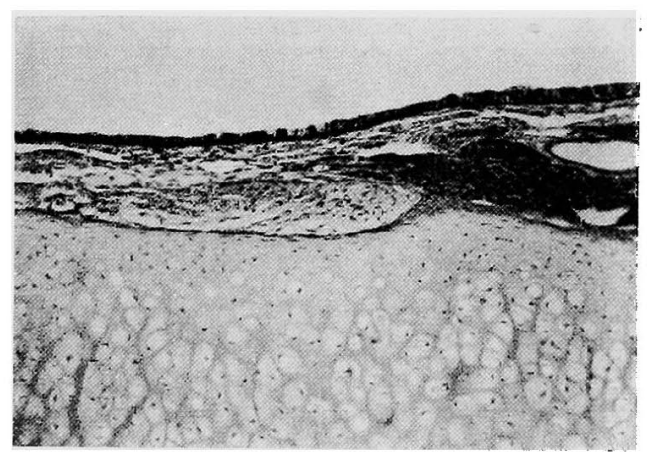

第 16 図 60 日目, 鼻中隔粘膜採取部, HE. 弱拡

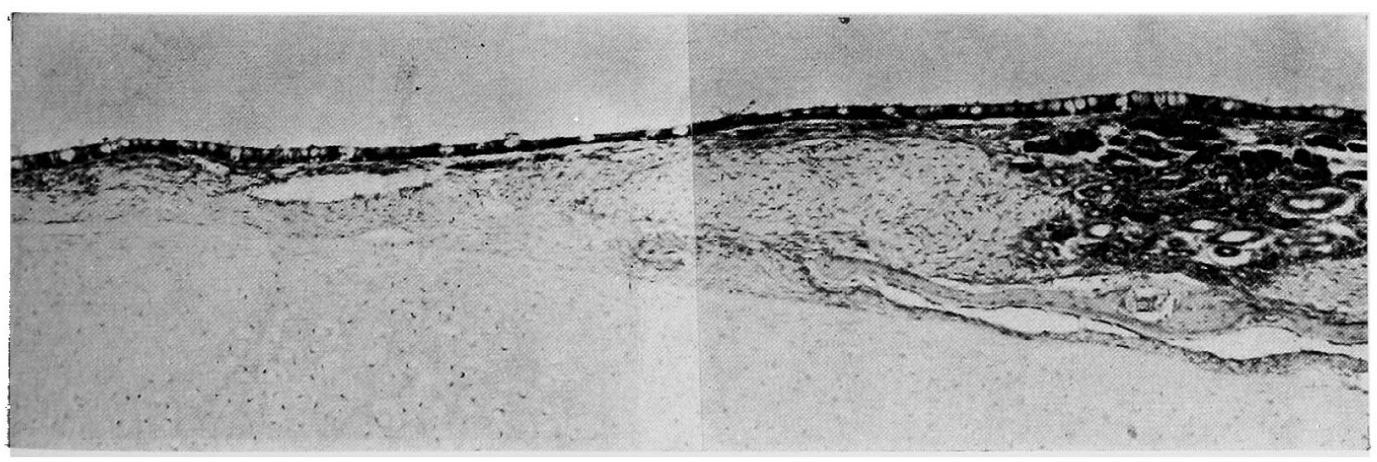

第 17 图 90 日目，甪中隔粘膜採取部，HE. 弱挾（左方は粘膜採取部，右方は本来の奥中隔粘膜） 


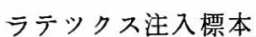

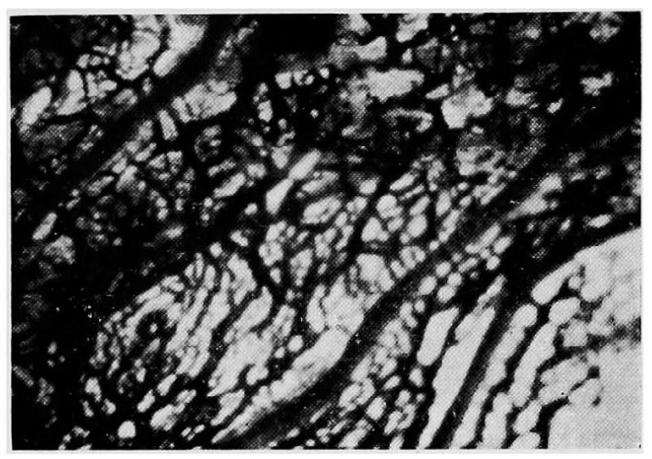

第 18 図対随, 鼻中隔前部粘膜血管.

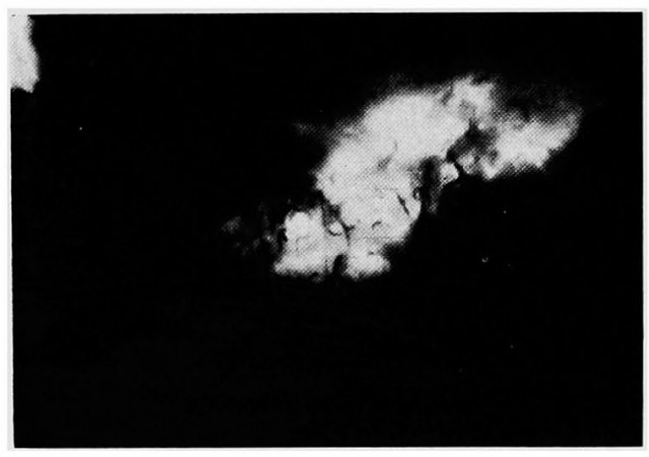

第20図4 日目, 強いラテックス漏洩.

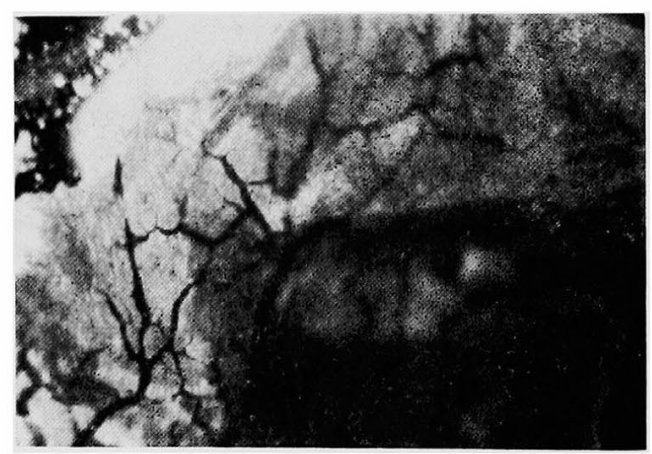

第 22 图 21 日目, 樹枝状の血管新生. 拡張, 蛇行.

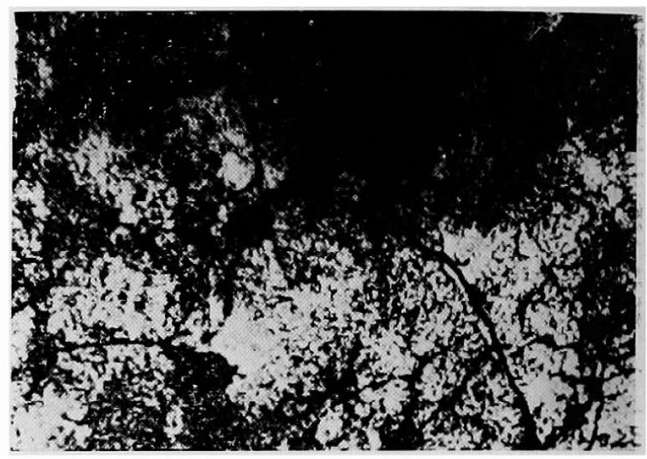

第 19 図対照, 上皮洞粘膜血管.

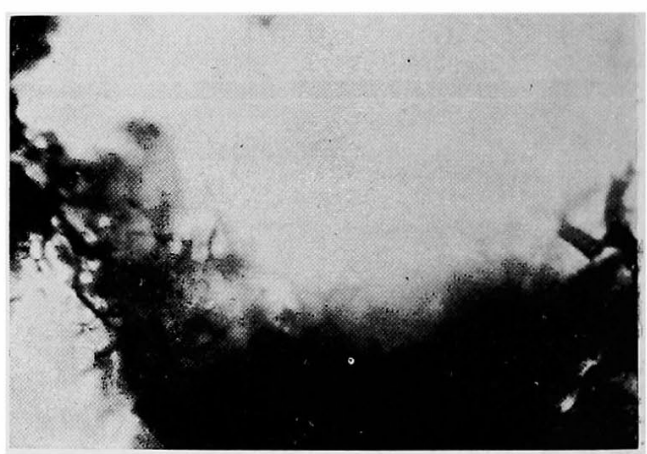

第 21 图 7 日目, 網限の形成が一部にみられる.

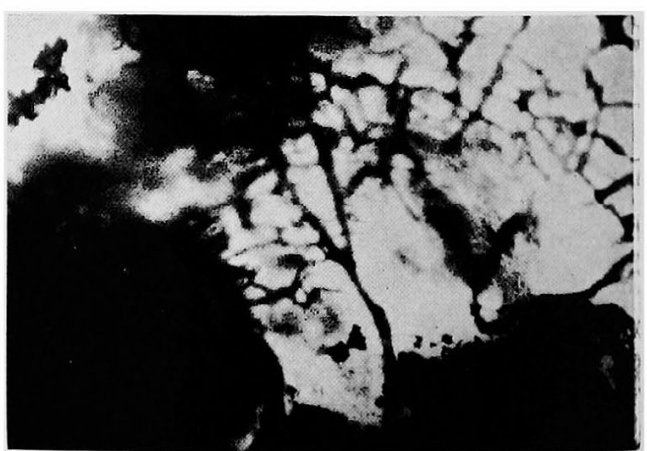

第 23 図 90 日目，上䫇洞に匹敵する血管新生. 
322, 1930.49$)$ Shirai (白井豹他)：動物実験の实 祭，206，1933（昭 8)，金原商店。50）Shiraiwa

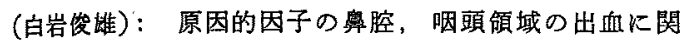
才百研究分析的研究，日耳算，62:2640，1959 (昭 34). 51) Sternberg, H. et al.: Beitrg zur Physiologie und Pathologie der Schleimhaut der Luftwege. 1. Die Veränderung der Nasenschleimhaut bei ausgeschalteter Nasenatmung. Z. HNO-hk. 7: 432, 1924. 52）Suzuki（鈴木貞一）：慢性上頻洞资根本手術後飞

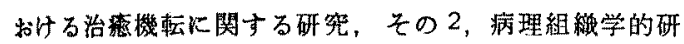
笔，京府医大誌，6：715，1932（昭 7). 53) Swindle, P.F.: The architecture of the blood vascular networks in the erectile and secretory lining of the nasal passage. Ann. Ot. etc. $44: 913,1935 . \mathrm{Na}$ sal blood vessels which serve as arteries in some mammals and as veins in some others. Ann. Ot. etc. 46:600, 1937. 54) Tailor, M. et al.: The influence of the endocrine system on the nasal respiratory mucosa, J. Laryngo. 75: 1048, 1961.

55) Takeda (武田元一郎)：奥血管の研究, 日耳奥, 30: 74, 1924 (大 13). 56) Thanhoffer, L. V.: Untersuchungen über die Mitose der Flimmerzellen und der Regeneration des Wimperepithels. Z. Anat. Entw. 90:713, 1929. 57) Tiedemann, R.: Ueber der glomläre Gefässe der Nasenschleimhaut. Arch. Ohr-usw. Hk. 172: 257, 1958.

58) Tomoda (友田洋一)：副奥腔の慢性炎症並びに粘 液需腫以関寸る実験的研究，第 2 編，鼻粘膜移槒の串 験, 日耳年，61：548，1957（昭 32）。 59) Tonndorf: Beitrag zur Ausheilung der nach Luc-Cald- well operierten Kieferhöhle. Z. HNO-hk. 22: 54, 1928. 60) Trueta: Studies of the renal circulation 1947. 61) Wright, C.F.: Radical maxillary sinus operation, clinical and histologic findings on one hundred patients. Arch. Otolaryng. 12: 63, 1930. 62) Wustrow, F.: Die Funktionsentwicklung der menschlichen Nasenschleimhaut. Z. Laryng. usw. 38:689, 1959. 63) Yamanaka (山中

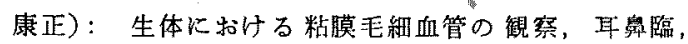
$50: 371,1957.64)$ Zarniko: Ueber die intraepitheliale Drüsen der Nasenschleimhaut. Interntionales Zb. f. H.N.O. $1: 440,1903 . \quad 65)$ Zöllner, F.: Knochenbildung aus Periostallappen bei Tym. panoplastik. Mschr. Ohrenk· 97. 51, 1953.

Zuckerkandle, E.: Gefäss der Nasenschleimhaut. Anatomie der Nasenhöhle. 1: 125, 1893, Wien.

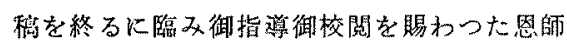
北村武教授に深甚なる謝意を捧げると共に本研 究にあたり直接労を共にし終始御指導御協力を 頂いた河野寿博士に或心から感謝の意を表しま す。そして適切な御助言を顶いた奥田稳助教授 に梁謝し，組織標本作慗に当り御指導頂いた佐 藤俊一博士，並びに研究に御協力頂いた教室員 各位に感謝いたします。

本諭女の要旨は日耳臱関東地方会第 46 回大 会に打いて発表した。

（原嘣到着 $=$ 昭和 39.12 .22 日） 